\title{
Association of Cognitive, Affective, Psychomotor and Intuitive Domains in Education, Sönmez Model
}

\author{
Veysel Sönmez \\ Faculty of Education, Cyprus International University, Cyprus
}

Copyright $\bigcirc 2017$ by authors, all rights reserved. Authors agree that this article remains permanently open access under the terms of the Creative Commons Attribution License 4.0 International License

\begin{abstract}
Problem statement: Educational goals are classified taxonomically as cognitive, affective, psycho-motor and intuitive. Can these classifications be associated? Sönmez's model represents an attempt for this. Purpose of Study: Is the model regarding the association of four domains developed by Sönmez supported significantly by empirical data? What are the views of the participants on this issue? Methods: Both qualitative and quantitative data were used together in this study. Findings and Results: A high level of significant and positive correlation was found between cognitive, psychomotor, affective and intuitive learning outcomes. Based on these findings, it can be stated that learning outcomes are not disconnected. That means when an individual learns a cognitive behavior he/she also learns other associated psychomotor, affective, and intuitive behaviors. Leaning is codded into four domains altogether. Conclusion and recommendations: This study revealed results supporting the model regarding the association of four domains as suggested by Sönmez. These results can be a proof of the hypothesis that behaviors of all domains are coded and learnt as a whole in the brain. Further comprehensive experimental and qualitative research can be done about this issue.
\end{abstract}

Keywords Learning Gains, Cognitive, Affective, Psychomotor, Intuitive Learning Outcomes, Education, Sönmez Model

\section{Introduction}

There is a good number of research conducted and theories developed about learning and teaching so far. There are many distinct definitions of learning according to these researches and theories [25, 29]. As the brain-related researches increased recently, many proofs have been found suggesting that learning takes place in the brain $[6,29]$. In this respect, learning can be defined as "the process of creating cultural change in the brain as a result of bio-chemical effects aroused by physical stimulants and the dynamic outcomes of this process" [29]. As it can be understood from this definition, learning can be regarded both as a process and an outcome of this process. These outcomes can be classified as desired, undesired, and unexpected outcomes. Education includes the desired outcomes.

Many researchers have been conducted and theories have been developed about the nature of desired learning outcomes. Learning outcomes have been classified taxonomically in different ways. These taxonomical classifications are generally named as cognitive, psycho-motor, affective and intuitive [28].

The terms taxonomy is derived from natural sciences. It refers to the gradual classification of creatures ranging from simple to complex and as constituting the prerequisite of each other. It was thought that learning outcomes can also be classified gradually in a similar way. There can be requirements to meet while forming taxonomical classifications. They are listed below:

1. How the learning outcome begin to develop and with which pattern it emerged;

2. Whether the learning outcome is the prerequisite of another learning outcome: the prerequisite behaviors should take part at first step and the latter should come after;

3. Learning outcomes should be ranged gradually from simple to complex, from easy to difficult: simple and easy learning outcomes should take part first and the complex and difficult outcomes should come after;

4. The order of the cultural outcome to be taught and the order followed while teaching them (i.e. which steps the learners go through while they are learning the behavior, and what is the character or nature of their behaviors at these steps) should be watched;

5. It should be ensured that the desired cultural learning outcomes to be taught are ordered from simple to complex, from easy to difficult, from concrete to abstract, from close to far, from today to the past, and so as to constitute a prerequisite for another learning outcome, as well as that they have both vertical and horizontal integration with other 
domains. That means all desired cultural learning outcome taught fall into not only the cognitive domain, but also into the other learning domains, thus the individuals learn the outcome as a whole and react [24, 26,27]. In this respect, no learning outcome can fall into a single domain. A learned behavior is in association with all domains. However, some educators believed that learning outcomes fall into a certain domain only. They developed their own classifications disregarding the other domains, which is a big mistake. The data obtained so far have proved that no behavior or outcome fall into a single domain alone. For example, when solving word problems in mathematics, the learning outcome falls mostly into cognitive domain. However, it is associated with the affective, psycho-motor and intuitive domains at the same time. This may be true for all behaviors, all learning outcomes.

In this respect, there isn't any taxonomy in education, which possesses all of the features mentioned above. In this situation, only those which are compatible with the characteristics of the taxonomy were taken as the basis. Others have been rearranged taxonomically according to the data.

There are several scholars who classified cognitive domain taxonomically [28]. Among them Bloom's classification has been accepted widely [3]. Revised by Krathwohl et al. later on, his taxonomy has been long used in the field of education [10].

Psychomotor domain has been classified by many educator in different ways [28]. Among these taxonomical classifications, Simpsion's classification has been used as the basis. This classification has been revised and presented by Sönmez [21].

The taxonomy of intuitive domain has been developed only by Sönmez. While classifying this domain, the characteristics of a taxonomy was taken into consideration. Moreover, harmony with the classifications of the other domains was ensured [28].

In terms of affective domain the taxonomical classification by Krathwohl has been adopted [4, 9]. Horizontal transitivity has been considered for the association of the four domains in all these classifications. Moreover, vertical progressivity has also been taken as a basis.

The cognitive, affective, psycho-motor and intuitive classifications have been handled altogether here. None of the learned behaviors are disconnected from each other at all. For example, someone who proposes a solution to a major problem caused by "immigration to metropolis", can use a set of concepts, principles, methods, or surveys while solving the problem. One can make an appointment and interview the relevant individuals. Or one can make telephone conversations. One concentrates on the problem. One can feel happy when one proposes valid solutions to the problems; or can feel uneasy or sad when unable to propose a valid solution. As it is seen in this single example, to propose a solution and to using concepts, principles, and methods for it is a cognitive activity. Preparing a survey and delivering it, getting appointments from the relevant people, interviewing them, concentrating an issue is a learned psycho-motor behavior. Feeling happy when proposing availed solution to the problem, enjoying cooperating with friends, adopting this attitude, or feeling uneasy or unhappy when one cannot dissolve the problem falls into affective domain. Saying that a certain person will help and having such a help in the future is intuitive. Thus, no matter how the learned behaviors are handled, they are not disconnected from each other. On the contrary, there is a significant and strict horizontal and vertical association between them. This may even mean that one cannot exist without the other. Therefore, the number of the steps of each domain must be the same. If the Cognitive domain has five steps, affective, psychomotor, and intuitive domains must be structured in fine steps. All domains should start from a certain point and end up at a certain point. That being the case, learning goals is likely to be classified taxonomically as follows: In this model, Bloom's cognitive domain, Krathwohl's affective domain and Sönmez's psycho-motor and intuitive domains were taken as the basis in coding, since these four domains have been tailored according to all the principles cited above.

Table 1. Sönmez's Model: Association of Cognitive, Affective, Psychomotor and Intuitive Domains in Education

\begin{tabular}{|c|c|c|c|}
\hline Cognitive Domain & Affective Domain & Psychomotor Domain & Intuitive Domain \\
\hline \multicolumn{4}{|c|}{ Perception } \\
\hline $\begin{array}{l}\text { 1. Knowledge } \\
\text { (Evaluation of the knowledge) } \\
\text { 2. Comprehension } \\
\text { (Evaluation of the Comprehension) } \\
\text { 3. Application } \\
\text { (Evaluation of Application) } \\
\text { 4. Analysis } \\
\text { (Evaluation of Analysis) } \\
\text { 5. Synthesis } \\
\text { (Evaluation of Synthesis) }\end{array}$ & $\begin{array}{l}\text { 1. Receiving } \\
\text { (Evaluation of receiving) } \\
\text { 2. Responding } \\
\text { (Evaluation of responding) } \\
\text { 3. Valuing } \\
\text { (Evaluation of valuing) } \\
\text { 4. Organization } \\
\text { (Evaluation of organization) } \\
\text { 5. Characterization } \\
\text { (Evaluation of characterization) }\end{array}$ & $\begin{array}{l}\text { 1. Excitement } \\
\text { (Evaluation of excitement) } \\
\text { 2. Making Manuel Control } \\
\text { (Evaluation of making manual } \\
\text { control) } \\
\text { 3. Skill } \\
\text { (Evaluation of skill) } \\
\text { 4. Fitting situation } \\
\text { (Evaluation of fitting situation) } \\
\text { 5. Creating } \\
\text { (Evaluation of creating) }\end{array}$ & $\begin{array}{l}\text { 1. Recognizing } \\
\text { (Evaluation of recognizing) } \\
\text { 2. Discrimination } \\
\text { (Evaluation of discrimination) } \\
\text { 3. Inside Born } \\
\text { (Evaluation of inside born) } \\
\text { 4. Retention Under Control } \\
\text { (Evaluation of retention under } \\
\text { control) } \\
\text { 5. The future-past Relationship } \\
\text { Building } \\
\text { (Evaluation of future-past } \\
\text { relationship building) }\end{array}$ \\
\hline
\end{tabular}


As seen in table Table 1, in this model learned behaviors have been taken as cognitive, affective, psycho-motor and intuitive. The learning goals of all courses can be determined as cognitive, affective, psycho-motor and intuitive, according to the gradual sequence to be followed in determining the objectives and the characteristics of the open system. As it is seen in table all four domains have the feature of horizontal integration and vertical progressivity. That means the steps of each domain is the prerequisite of each other. Comprehension needs knowledge, application needs comprehension, analysis need application, and synthesis need all of the previous. However, in my opinion after each step evaluation can be done. This can be true for all domains and each of their steps. The evaluation after knowledge is the evaluation of knowledge; evaluation after comprehension is that of comprehension; evaluation after application is that of application; evaluation after analysis is that of analysis; and evaluation after synthesis is the evaluation of synthesis. The evaluation of all these evaluations can be considered as the last step, because in evaluation new criteria and measures should be found and used. Developing and using a new measure can be thought to be a behavior beyond synthesis. Similarly, the same progressivity and evaluation are valid for affective, psycho-motor and intuitive domains. Horizontal integration means that a person who learns a behavior at the knowledge step of cognitive domain is at the reception step of affective domain, excitement step of psychomotor domain, and recognizing step of intuitive domain. All learned behaviors can begin with perception and end with evaluation, because the organism cannot react at all without perceiving the stimulant and if there is no learned behavior it cannot make any evaluation. Though cognitive processes are more dominant, evaluation is related with all learning domains. Human can evaluate his knowledge, skills, feelings and intuitions in any domain and any steps of each domain based on certain criteria [26].

Learning outcomes are very important in education. These outcomes can be designated according to taxonomies. It may enhance education to make taxonomies more reliable and useful for education. Thus, more valid and reliable educational systems can be prepared, which in turn will enable learners to learn better and be successful.

\subsection{Research Question}

Is the model regarding the association of four domains developed by Sönmez supported significantly by empirical data? What are the views of the participants on this issue?

\section{Method}

\subsection{Research Design}

In this research, the quantitative survey method and qualitative focus group methods were used together. The quantitative survey study involved ninety people who are either successful or unsuccessful in their fields. Their success in their fields were proved relying on the official documents. The sample included three subgroups each with 30 people distinguished into three levels of achievers (low, moderate and high): first group (low achievers) included thirty people who studied in different fields and failed, second group (moderate achievers) included thirty people who studied in different fields and achieved moderately, and third group included thirty people who are extremely successful with a PhD degree. Statistical analysis were done on data obtained from these groups. Next, nine volunteers were selected randomly from among these ninety people and focus group interviews were done with them. The qualitative data obtained from the focus group interviews were analyzed using descriptive and descriptive interpretive content analysis in depth, as well as discourse, speech and metaphor analysis [30].

To collect the quantitative data tests for affective and intuitive domains were developed. To develop these tests, first the resources, researches, and instruments in the relevant literature were examined. A total of 15 and 13 observable and measurable traits were determined respectively for affective and intuitive domains. A panel of three experts were consulted to evaluate the approach of these 15 and 13 traits. As a result 12 of the traits were included in affective domain test and 8 traits were included in intuitive domain test. The agreement between these three experts was tested, which revealed inter-rater reliability coefficient of .83 for affective domain and .78 for intuitive domain, which can be considered as a proof for the content validity of the tests. The reliability of the tests were estimated using Cronbach Alpha internal consistency coefficients, which yielded .81 for affective domain test and .76 for intuitive domain test.

After all these steps, both tests were subjected to factor analysis. For this reason, first the sampling adequacy of the data set was tested using Kaiser Meyer-Olkin analysis. As a result of this analysis KMO coefficients of .84 and .74 were found for affective and intuitive domain tests respectively. These coefficients indicate a high adequacy of the samples. Next, the significance of the results of Bartlett's Test of Sphericity was tested as a prerequisite of factor analysis [30]. These values were also found significant (Affective domain= $4114.8, \mathrm{p}<.05$ and Intuitive domain=3456.4, $\mathrm{p}<.05$ ). After securing these two conditions, the data sets were subjected to factor analysis.

The initial principle components factor analysis for both instruments yielded high variance explanation rates, $76 \%$ for affective domain and $72 \%$ for intuitive domain. Though these can be considered adequate, but output in total variance explained table can be deceptive while exploring the construct of an instrument. Therefore, the eigenvalues, Scree Plot graphics, and factor loadings were examined further. Since eigenvalues for the first factors for both instruments were considerably higher than the eigenvalues of the other factors, the instruments were fixed to single factor, and other factors were disregarded since their eigenvalues were small and close to each other. Since there were no overlapping or excessively low $(<.30)$ factor loadings, no variable was excluded from the analysis. Thus scales were made ready for use (30). 
Table 2. The Distribution Of The Participants According To Achievement Group And Majors

\begin{tabular}{|c|c|c|c|c|c|c|c|c|c|}
\hline Group & Education & Social & Science & Engineering & Health & Technology & Sports & $\begin{array}{c}\text { Fine } \\
\text { arts }\end{array}$ & Total \\
\hline Very low achiever & 3 & 3 & 4 & 4 & 4 & 4 & 4 & 4 & 30 \\
\hline Moderate achiever & 3 & 3 & 4 & 4 & 4 & 4 & 4 & 4 & 30 \\
\hline High-achiever & 3 & 3 & 4 & 4 & 4 & 4 & 4 & 4 & 30 \\
\hline Total & 10 & 10 & 10 & 10 & 10 & 10 & 10 & 10 & 90 \\
\hline
\end{tabular}

\section{Findings and Results}

\subsection{Participants' Profiles}

The distribution of the low-, moderate- and high-achiever undergraduate-to-postgraduate participants according to their majors are given in Table 2.

According to Table 2, out of ninety participants 30 were very low-achievers, 30 were moderate achievers, 30 were high-achievers who got a $\mathrm{PhD}$ degree. Each major was represented with ten students. The distribution of these students across different majors and achievement groups is equal.

\subsection{Participants' Levels Of Cognitive And Psycho-motor Learning Outcomes}

Table 3 shows the means and variance analysis results regarding the achievement scores obtained by the very low-achiever and moderate achiever undergraduate students and high-achiever $\mathrm{PhD}$ students from Cognitive and Psychomotor courses.

Table 3. The Mean Achievement Scores In Cognitive And Psychomotor Courses And F Values For Participants Cognitive

\begin{tabular}{cccccc}
\hline & $\begin{array}{c}\text { Sum of } \\
\text { Squares }\end{array}$ & df & $\begin{array}{c}\text { Mean } \\
\text { Square }\end{array}$ & F & Sig. \\
\hline $\begin{array}{c}\text { Between } \\
\text { Groups }\end{array}$ & 61,280 & 2 & 30,640 & 566,678 &, 000 \\
Within Groups & 4,650 & 86 &, 054 & & \\
Total & 65,930 & 88 & & & \\
\hline
\end{tabular}

As it is seen in the table, the significant differences between the academic achievement scores of the students were tested with one way analysis of variance. The $f$ value was estimated 566.678. Since it was higher than the value referring to the significance level of .01 and degree of freedom of 88 in the table, there was a significant difference between the academic achievement scores of the groups. In order to find out the source of difference, each group was compared to each other using independent samples $t$ test. The results of $t$ test analysis are given in table 4 .
Table 4. Results Of $\mathrm{T}$ Test Analysis For The Academic Achievement Scores Of The Groups

\begin{tabular}{cccccc}
\hline Groups & $\mathrm{n}$ & $\bar{x}$ & $\mathrm{~S}$ & $\mathrm{t}$ & $\mathrm{p}$ \\
\hline Very low-achievers & 30 & 1,69 & .05 & $\begin{array}{c}\text { Very low vs. } \\
\text { moderate } \\
\text { Very low vs. }\end{array}$ &, 000 \\
Moderate-achievers & 30 & 2,84 & .22 & $\begin{array}{c}\text { Moderate vs. } \\
\text { high }=16.51\end{array}$ &, 000 \\
High-achievers & 30 & 3,72 & .87 & & \\
Total & 90 & & & & \\
\hline
\end{tabular}

As it is seen in Table 4, the significant differences between the academic achievements mean scores of the groups were tested using $t$ test. The academic achievement mean scores of all three groups were found significantly different at 01 level.

\subsection{Affective Learning Outcomes of the Participants}

The means and variances of the scores obtained by the very low-, moderate- and high-achiever students from affective domain test are presented Table 5 .

Table 5. F Test Results Of The Participants' Scores From Affective Domain Test

\begin{tabular}{cccccc}
\hline & $\begin{array}{c}\text { Sum of } \\
\text { Squares }\end{array}$ & df & Mean Square & F & p \\
\hline $\begin{array}{c}\text { Between } \\
\text { Groups }\end{array}$ & 18165,489 & 2 & 9082,744 & 408,907 &, 000 \\
Within & 1932,467 & 87 & 22,212 & & \\
Groups & & & & \\
Total & 20097,956 & 89 & & & \\
\hline
\end{tabular}

As it is seen in the table, the significant differences between each group's mean scores from the affective domain were tested with one way analysis of variance. The $F$ value was estimated 408.907. Since it was higher than the value referring to the significance level of .01 and degree of freedom of 87 in the table, there was a significant difference between the affective mean scores of the groups. In order to find out the source of difference, each group was compared to each other using independent samples $t$ test. The results of $\mathrm{t}$ test analysis are given in table 6 . 
Table 6. Results Of T Test Analysis For The Affective Scores Of The Groups

\begin{tabular}{cccccc}
\hline Groups & $\mathrm{n}$ & $\bar{x}$ & $\mathrm{~S}$ & $\mathrm{t}$ & $\mathrm{p}$ \\
\hline $\begin{array}{c}\text { Very low } \\
\text { achievers }\end{array}$ & 30 & 34.20 & 4,68 & $\begin{array}{c}\text { Very low vs. } \\
\text { moderate =13.56 } \\
\text { Very low vs. } \\
\text { high=34.03 }\end{array}$ &, 000 \\
Moderate & 30 & 49.90 & 5.94 & $\begin{array}{c}\text { Moderate vs. } \\
\text { high = 13.14 }\end{array}$ &, 000 \\
$\begin{array}{c}\text { achievers } \\
\text { High-achievers }\end{array}$ & 30 & 65.97 & 3.09 & & \\
Total & 90 & & & & \\
\hline
\end{tabular}

As it is seen in Table 6 , the significant differences between the affective mean scores of the groups were tested using $t$ test. The affective mean scores of all three groups were found significantly different at 01 level.

\subsection{Intuitive Learning Outcomes of the Participants}

The means and variances of the scores obtained by the very low-, moderate- and high-achiever students from intuitive domain test are presented Table 7 .

Table 7. F Test Results Of The Participants' Scores From Intuitive Domain Test

\begin{tabular}{cccccc}
\hline & Sum of Squares & df & $\begin{array}{c}\text { Mean } \\
\text { Square }\end{array}$ & F & Sig. \\
\hline $\begin{array}{c}\text { Between } \\
\text { Groups }\end{array}$ & 3873,156 & 2 & 1936,578 & 432,043 &, 000 \\
$\begin{array}{c}\text { Within } \\
\text { Groups }\end{array}$ & 389,967 & 87 & 4,482 & & \\
Total & 4263,122 & 89 & & & \\
\hline
\end{tabular}

As it is seen in the table, the significant differences between each group's mean scores from the intuitive domain test were tested with one way analysis of variance. The $\mathrm{F}$ value was estimated 432,043 . Since it was higher than the value referring to the significance level of .01 and degree of freedom of 87 in the table, there was a significant difference between the intuitive mean scores of the groups. In order to find out the source of difference, each group was compared to each other using independent samples $t$ test. The results of $\mathrm{t}$ test analysis are given in table 8 .

Table 8. Results Of T Test Analysis For The Intuitive Mean Scores Of The Groups

\begin{tabular}{cccccc}
\hline Groups & $\mathrm{N}$ & $\bar{x}$ & $\mathrm{~S}$ & $\mathrm{~T}$ & $\mathrm{p}$ \\
\hline Very Low-achievers & 30 & 24.9 & 2.47 & $\begin{array}{c}\text { Very low vs. } \\
\text { moderate } \\
=13.00\end{array}$ &, 000 \\
Very low vs. &, 000 \\
high =29.76 & \\
Moderate-achievers & 30 & 37.7 & 2.17 & $\begin{array}{c}\text { Moderate vs. } \\
\text { high =16.70 }\end{array}$ &, 000 \\
High-achievers & 30 & 40.9 & 1.63 & & \\
Total & 90 & & & & \\
\hline
\end{tabular}

As it is seen in Table 8, the significant differences between the intuitive mean scores of the groups were tested using $t$ test. The intuitive mean scores of all three groups were found significantly different at 01 level.

\subsection{Participants Levels of Affective and Intuitive Learning Outcomes}

The results of Pearson Moments Correlation analysis regarding the association between the affective and intuitive domain scores of the very low-achiever and moderate-achiever undergraduate students and high-achiever PhD students are presented in Table 9.

Table 9. The Association Between Groups' Affective And Intuitive Scores

\begin{tabular}{cccc}
\hline & & VAR00003 & VAR00004 \\
\hline & Pearson Correlation & 1 &, $909^{* *}$ \\
VAR00003 & Sig. (2-tailed) & &, 000 \\
N & 90 & 90 \\
VAR00004 & Pearson Correlation &, $909^{* *}$ & 1 \\
& Sig. (2-tailed) &, 000 & \\
& $\mathrm{~N}$ & 90 & 90 \\
\hline
\end{tabular}

**. Correlation is significant at the 0.01 level (2-tailed).

As it is seen in Table 9, the association between groups' affective scores and intuitive scores was tested using Pearson Moments Correlation analysis. The correlation coefficient was found .909 in the positive direction. This coefficient indicates a significant positive and high correlation between groups' affective and intuitive scores. In this context, it can be said that as one's affective score decrease, his intuitive scores also decrease, and vice versa.

\subsection{Participants Levels of Cognitive, Psychomotor, Affective and Intuitive Learning Outcomes}

The results of Pearson Moments Correlation analysis regarding the association among the cognitive, psychomotor and affective domain scores of the very low-achiever and moderate-achiever undergraduate students and high-achiever PhD students are presented in Table 10.

Table 10. The Association Between Groups' Cognitive, Psychomotor, And Affective Scores

\begin{tabular}{cccc}
\hline & & VAR00003 & VAR00002 \\
\hline & Pearson Correlation & 1 &, $917^{* *}$ \\
VAR00003 & Sig. (2-tailed) & &, 000 \\
& N & 90 & 90 \\
VAR00002 & Pearson Correlation &, $917^{* *}$ & 1 \\
& Sig. (2-tailed) &, 000 & \\
& N & 90 & 90 \\
\hline
\end{tabular}

**. Correlation is significant at the 0.01 level (2-tailed).

As it is seen in Table 10, the association between groups' 
cognitive, psychomotor and affective scores was tested using Pearson Moments Correlation analysis. The correlation coefficient was found .917 in the positive direction. This coefficient indicates a significant positive and high correlation between groups' cognitive and psychomotor achievement scores and affective scores. In this context, it can be said that as one's achievement scores in cognitive and psychomotor domains decrease, his affective scores also decrease, and vice versa.

A total of nine students randomly selected out of ninety volunteered to take part in the follow-up focus group interviews. In this respect, semi-structured focus group interviews were conducted with three students from each of the three groups. Students' responses in focus group interview questions are as follows:

\section{Question: How do you feel when you fail? Can you explain with examples?}

Very low achiever participant $\mathrm{l}$ : Sir, my interest in the lesson is exhausted. I don't want to learn and study. I believe my failure stems from my lack of knowledge about the topics. When I don't know I don't understand, and can't solve the problems. Then everything gets dark. Fear begins.

Very low achiever participant 2: I went to the laboratory for the first time in my life. There were many equipment I didn't know. What is going to happen now!.. Going to do an experiment!.. How will I use those equipment? I didn't know. I can cause an accident, I can get into trouble... I said myself to keep away from them. I couldn't achieve because I didn't know. I failed. I didn't want to learn anymore.

Very low achiever participant 3: I got poor grades in the first exams. As I got poor grades, the feeling that I would fail became an obsession. My interest in the lesson decreases. As it decreased I begin to dislike the lesson and the lecturers. I didn't want to learn. I exceeded the absence limit. Everything including books, notes seemed like enemies to me. So I sought refuge in cafes, internet, gangs, telephone communication, and face book.

\section{Question: How do you feel when you are successful? Can you explain with examples?}

Moderate achiever student 1: I think it is ok to learn the amount of knowledge and skills enough to pass the course. I don't want to be a swot. I am not here to learn knowledge, and skills only. I will live my life to the fullest.

Moderate achiever student 2: I like to learn new things one after another. However, it has limits. Having too much knowledge and competence may depress me mentally. It is enough for me to know and do what is taught. I should spare some time for myself to do other things. This amount of knowledge and competence is enough for me to live my youth.
Moderate achiever student 3: We don't live to study only. Life means to have fun, travel, do new things, meet and get new friends. There is no knowledge or skills taught by the teachers to get all these. They only ask us to work in the lab, do that experiment, and check the results. Then they say "You failed to find the correct result. Try it again." I can't do with what I have learnt, and when I can't do I don't want to learn more. That's more than enough, if it suffices to pass the course.

\section{Question: How do you feel when you are very successful? Can you explain with examples?}

High achiever student 1: I don't have fee time. I always think about the experiments. I ask myself "How can I achieve the same results from the experiments?" I see all those machines, equipment, and devices in my dreams. I set reassemble them all over and over again. I like it very much to improve my knowledge and skills. It is a pleasure for me to learn something new. Thus, Google is my best friend.

High achiever student 2: I do not have free time, either. I might have free time, if a day were 96 hours long. As I learn new things I notice how less I know. Especially after I complete an experiment or resolve a problem, I always ask myself "How can I do this experiment in a different way?", or "How can I solve this problem in another way?" I seek answers for these questions. There are times I think about or look for different ways and methods. I like these kind of activities. After I understand the reason behind the phenomena, and practice them, I can't stop just there. The question "Can I find another way or solution?" keeps on straining my mind.

High achiever student 3: Before sleeping at night I always ask myself "What have I learned today?" If I haven't learned something new, I open the medical dictionary and learn a new term. We don't memorize things. We have to examine the patient correctly, ask for the correct tests, diagnose the problem correctly and cure the patients. This is what my profession requires. The more I learn the more I want to learn. Especially when I cure a patient, I become very happy. I keep the record of that disease, tests, and the medication I prescribed. Most of the time, I consult to my professors and fellows about the issues that I cannot solve or decide, and try to solve them. I understand better after each patient that I am so illiterate and so inexperienced. As Socrates said "All I know is I know nothing". I feel very happy to attend to conferences, panels, sessions about my expertise, and to listen to the speakers' experiences. This life is exactly my type. It gives me terrifying pleasure to learn, and use whatever I have learnt to cure my patients, that's all.

The results of Pearson Moments Correlation analysis regarding the association among the cognitive and psychomotor competency scores and intuitive domain scores of the very low-achiever and moderate-achiever undergraduate students and high-achiever PhD students are presented in Table 11. 
Table 11. The Association Between Groups' Cognitive And Psychomotor Competences And Their Intuitive Scores

\begin{tabular}{cccc}
\hline & & VAR00002 & VAR00004 \\
\hline & Pearson Correlation & 1 &, $925^{* *}$ \\
VAR00002 & Sig. (2-tailed) & &, 000 \\
& N & 90 & 90 \\
VAR00004 & Pearson Correlation &, $925^{* *}$ & 1 \\
& Sig. (2-tailed) &, 000 & \\
& N & 90 & 90 \\
\hline
\end{tabular}

**. Correlation is significant at the 0.01 level (2-tailed).

As it is seen in Table 11, the association between groups' cognitive and psychomotor competence scores and intuitive domain scores was tested using Pearson Moments Correlation analysis. The correlation coefficient was found .925 in the positive direction. This coefficient indicates a significant positive and high correlation between groups' cognitive and psychomotor achievement scores and intuitive domain scores. In this context, it can be said that as one's achievement scores in cognitive and psychomotor domains decrease, his intuitive scores also decrease, and vice versa.

A total of nine students randomly selected out of ninety volunteered to take part in the follow-up focus group interviews. In this respect, semi-structured focus group interviews were conducted with three students from each of the three groups. Students' responses in focus group interview questions are as follows:

Question: Can you predict in advance the outcomes of a research (an experiment, an application, a piece of art, a piece of art, or competition)? Can you explain with examples?

Very low achiever I: Sir, I have never did any experiment! What result can I predict? I study physics. When I go into a lab, I am scared to death. I don't know the equipment. How can I predict anything about an issue I don't know, can you tell me?

Very low achiever 2: I agree with my fellow. I have never delivered a lesson at primary school. I was very confused when I first saw the students. Furthermore, I didn't know anything correctly. I don't know how to quieted the class without beating any students, or how to maintain the discipline. My knees began to knock together. Moreover, I forgot everything. I was ashamed. However, I hadn't thought I would be ashamed.

Very low achiever 3: I can't sense anything in advance about anything, especially about the subjects I fail. I can no way predict the conclusion of any philosophical, or scientific text. All my predictions go wrong. And this makes me feel bad. I lose my self-confidence. My motivation to learn is destroyed. I feel like I get a counter punch. I can't stand up any more.
Moderate achiever I: I will keep it short professor. I can predict the results of familiar or similar experiments; but not the new ones. Most results I predict are wrong,

Moderate achiever 2: I can easily predict the implications of the writings of familiar authors correctly. In most cases, I can't predict the end of a text I read for the first time. I usually can't find the criminal, which makes me sad. I get angry with myself.

Moderate achiever 3: Sometimes I just have a feeling. It says I am going to win that competition. To my surprise, it happens so. I think I may have kind of astrology skills. But I cannot predict the winner of a race with unfamiliar runners, since I don't know the properties of the athletes. I believe this depends on knowledge.

High achiever 1: When we are working in the workshop, usually I can sense in advance whether there will be a power cut. Before the power cut, I check the power supply instantly. I can guess the failures in machinery from their sounds. Now I am able to understand the language of the machinery, the job. It is like I can enter into their spirits. This gives me confidence and happiness.

High achiever 2: As I make all those researches, I have become specialized now. I have learned every single detail. I can predict almost definitely whether the hypothesis will be accepted or not just looking at the problem statement of a research. This gives me power, confidence and pride. I believe that knowledge is the power. I burn the midnight oil to learn new things. Nobody can prevent me from making research. As the phrase goes I have become a research maniac.

High achiever 3: As you know, I am studying for specialization in medicine. Without examining the test results, I can diagnose my patients' diseases just by looking at their faces, the way they walk, and their intonation. I am over the moon when the test results support my diagnosis. I purr with delight. I trust in me that I will be a successful doctor. I have to tell you an interesting account about me. I was on duty at the hospital one night. I was very bored. It was like something happened to my mom and dad. The depression I felt grew more and more. I rushed to the phone. I could not have access either to my mom or dad. At that moment, the nurse came in. She said they called me from the ER. I went down to ER. I was shocked to see my mom lying on the gurney. She had a traffic accident. Her leg was broken. I could not forget that event. Intuitions are real, sir! I have experienced many times with my mom that there is an intuitive link between people who love each other very much.

\section{Conclusions and Recommendations}

As it can be understood from the findings of this study the affective and intuitive mean scores of the students who are not successful in cognitive-psychomotor domains are lower than those of other groups. The statements obtained in 
semi-structured focus group interviews such as "my interest in the lesson is exhausted, I believe my failure stems from my lack of knowledge about the topics. Fear begins. There were many equipment I didn't know. I can get into trouble... I couldn't do because I didn't know. I had an established feeling that I would fail. My interest into the lesson decreased. Lack of love. I didn't want to learn. Everything including books, notes seemed like enemies to me. "indicated the association between affective characteristics and academic achievement (in cognitive and psychomotor domains). As a matter of fact, the calculated correlation coefficient was high and in the positive direction (.917). Many research findings in this field also support this finding $[2,17,23,25,31,32]$.

As the students' academic achievement (cognitive-psychomotor) increases, there are also significant increase in their affective characteristics. As a matter of fact moderate achievers said that "I think it is ok to learn the amount of knowledge and skills enough to pass the course. I don't want to be a swot. I like to learn new things one after another. I like to learn new things one after another. I should spare some time for myself to do other things. Life means to have fun, travel, do new things, meet and get new friends. There is no knowledge or skills taught by the teachers to get all these. I can't do with what I have learnt, and when I can't do I don't want to learn more. That's more than enough, if it suffices to pass the course."

The high achievers on the other hand expressed themselves with more sentimental statements such as "I do not have free time. How can I do this experiment in a different way? I see all those machines, equipment, and devices in my dreams. I like it very much to improve my knowledge and skills. It is a pleasure for me. As I learn new things I notice how less I know. I always ask myself 'How can I do this experiment in a different way?' I like these kind of activities. After I understand the reason behind the phenomena, and practice them, I can't stop just there. The question 'Can I find another way or solution?' keeps on straining my mind. What have I learned today?" We have to examine the patient correctly, ask for the correct tests, diagnose the problem correctly and cure the patients. The more I learn the more I want to learn. I become very happy. I consult and try to solve them. I understand better after each patient that I am so illiterate and so inexperienced. As Socrates said 'All I know is I know nothing'. I feel very happy to attend to conferences, panels, sessions about my expertise, and to listen to the speakers' experiences. It gives me terrifying pleasure ... that's all." As the students' academic achievement in cognitive-psychomotor domains academic increase, their affective features also increase or vice versa. Based on this data it can be said that there is a high level of positive significant correlation between cognitive-psychomotor learning outcomes and affective learning outcomes. The previous research also support this finding $[1,5,7,12,19,25]$. Also a significant association was found between cognitive domain and attitude and motivation $[7,13,14,16,18,20,22]$. The significant high and positive correlation between cognitive-psychomotor learning outcomes and affective learning outcomes can be considered to prove the association of these domains with each other. In this context, it can be said that cognitive-psychomotor and affective learning outcomes are not independent. This result supports the model and the consideration proposed by Sönmez.

The correlation between intuitive data and cognitive-psychomotor academic achievement mean scores of the students was found to be significant, positive and high. The students with high academic achievement also have high intuitive scores, while students with low academic achievement have low intuitive scores. The statements uttered by very low achiever students during the semi-structured interviews included "When I go into a lab, I am scared to death. I don't know the equipment. How can I predict anything about an issue I don't know, can you tell me?; I have never delivered a lesson at primary school. I was very confused when I first saw the students. Furthermore, I didn't know anything correctly. I don't know how to quieten the class without beating any students, or how to maintain the discipline. My knees began to knock together. Moreover, I forgot everything. I was ashamed. However, I hadn't thought I would be ashamed; I can't sense anything in advance about anything, especially about the subjects I fail. I can no way predict the conclusion of any philosophical, or scientific text. All my predictions go wrong. And this makes me feel bad. I lose my self-confidence. My motivation to learn is destroyed. I feel like I get a counter punch. I can't stand up any more." The high achievers on the other hand stated that "usually I can sense in advance. I can guess the failures in machinery from their sounds. Now I am able to understand the language of the machinery, the job. It is like I can enter into their spirits. This gives me confidence and happiness. I have learned every single detail. I can predict almost definitely whether the hypothesis will be accepted or not just looking at the problem statement of a research. This gives me power, confidence and pride. I believe that knowledge is the power. I burn the midnight oil to learn new things. Nobody can prevent me from making research. As the phrase goes, I have become a research maniac; I can diagnose my patients' diseases. I am over the moon when the test results support my diagnosis. I purr with delight. I trust in me that I will be a successful doctor. I have to tell you an interesting account about me. I was on duty at the hospital one night. I was very bored. It was like something happened to my mom and dad. The depression I felt grew more and more. I rushed to the phone. I was shocked to see my mom lying on the gurney. I could not forget that event. Intuitions are real, sir! I have experienced many times with my mom that there is an intuitive link between people who love each other very much." As it can be understood from these statements, one can make correct predictions about the issues that he/she is informed, which may give him/her joy, pride, happiness and confidence. They cannot make predictions about the issues they do not know, or even they are afraid of. 
These findings suggest that there is a significant association between intuitive domain and learning outcomes in both affective and cognitive-psychomotor domains [8, 11, 15]. Moreover, the existence of a positive, high and significant correlation between cognitive-psychomotor learning outcomes and affective outcomes can be considered to be a proof of the association between these domains. Based on these results, the model regarding the association of cognitive-psychomotor, affective and intuitive domains in education as suggested by Sönmez can be advocated. That means, it can be said that all learning outcomes fall into all four learning domains together, and they are in horizontal association and vertical progressivity.

Further comprehensive experimental and qualitative research can be done about this issue to get more valid and reliable results. These studies can be conducted in long time. They can be recorded the videos. Based on the analysis of these video records, it can be tested whether four domains are learned together or not. The school curricula can be developed considering the association of the four domains. Teaching, learning, and evaluation procedures can be arranged accordingly.

\section{REFERENCES}

[1] Adler, R. W., Milne, M. J., \& Stablein R. (2001). "Situated Motivation: An empirical test in an accounting course", Canadian Journal of Administrative Sciences, 18 (2) 101-115.

[2] Beard, C., Clegg, S.,\& Smith, K. (2007). “Acknowledging the affective in higher education", British Educational Research Journal, 33/2 (2007), s. 235-252

[3] Bloom, B. S. (1956). Taxonomy of educational objectives, handbook I: Cognitive domain. New York: Longman-Green.

[4] Bloom, B. S., Hastings, T., \& Madaus, G.F. (1971). Handbook on formative and summative evaluation of student learning. New York: McGraw Hill

[5] Broekens, J., Kosters W, A.,\& Verbeek F. J. (2007).“Affect, Anticipation and Adaptation: Affect-controlled selection of anticipatory simulation in artificial adaptive agents", Adaptive Behavior, 15/4 (2007), s. 397-422.

[6] Caıne, G., Caıne, R.N., Mcclıntıc, C. \&Klımek, K. (2005). 12 Brain/Mind Learning Principles in Action, Thousand Oaks, CA: Corwin Press.

[7] Dembo, M. H. (2004). Motivation and learning strategies for college success: A Self-management approach, New York: Lawrence Erlbaum Associates.

[8] George, M. (2010). "Ethics and motivation in remedial mathematics education", Community College Review, 38(1) (2010), s.82-92.

[9] Krathwohl, D. R., Bloom, B. S., \& Masia. B. M. (1964). Toxonomy of educational objectives handbook II: Affective domain. New York: David Mckay.
[10] Krathwohl, D. R.(2002). “A revision of bloom's taxonomy: an overview", Theory Into Practice, Volume 41, Number 4, Autumn.

[11] Lehman, R. (2006). "The role of emotion in creating instructor and learner presence in the distance education experience", Journal of Cognitive Affective Learning, 2/2 (2006), s. 12-26.

[12] Lopes, P, N., Brackett, M. A., Nezlek, J. B., Schütz, A., Sellın, I. \& Salovey P.(2004). "Emotional intelligence and social 1nteraction", Personality and Social Psychology Bulletin, 30/8 (2004), s. 1018-1034

[13] Mousoulides, N., \& Philippou, G. (2005)."Students' motivational beliefs, self-regulation strategies and mathematics achievement in chick, H. L. \& Vincent, J. L. (Eds.). Proceedings of the 29th Conference of the International Group for the Psychology of Mathematics Education, Vol. 3, pp. 321-328. Melbourne: PME.

[14] Osborne, J., Simon, S., \& Collins, S. (2003). "Attitudes toward science: A Review of the literature and its implications", International Journal Of Science Education, 25(9), 1049-1079.

[15] Picard, R, W., Papert, S., Bender, W., Blumberg, B., Breazeal, C., Cavallo, D., Machover, T., Resnıck, M., Roy, D., \& Strohecker, C. (2004).“Affective learning-a manifesto", BT Technology Journal, 22/4 (2004), s. 253-269.

[16] Puurula, A., Neıll, S., Vasıleıou, 1., Husbands, C., Lang, P., Katz, Y, j., Romı, S., Menezes, I., \& Vriens 1. (2001). "Teacher and student attitudes to affective education: A European collaborative research project", Compare: $A$ Journal Of Comparative Education, 31/2 (2001), s. 165-186.

[17] Russell , M. (2004). "The Importance of the affective domain in further education classroom culture", Research in Post Compulsory Education, 9/2, (2004), s. 249- 270.

[18] Salta, K., \& Tzougraki, C. (2004). "Attitudes toward chemistry among 11th grade students in high schools in Greece", Science Education, (88), 535- 547.

[19] Scheindlın, L. (2003). "Emotional perception and spiritual development", International Journal of Children's Spirituality. 8/2, (2003), s. 179-193.

[20] Selvarajah, C., Chellıa, J., Meyer, D., P1o, E., \& Anurit, P.(2010). "The Impact of social motivation on cooperative learning and assessment preferences", Journal of Management Organization, 16 (2010), s.113-126.

[21] Simpson, E.J. (1966). The classification of educational objectives, psychomotor domain. Illinois Teacher of Home Economies, 1966, 10, 110-144.

[22] Sorge, C. (2007). "What happens? Relationship of age and gender with science attitudes from elementary to middle school", Science Educator, 16(2), 33-37.

[23] Thompson, T. L., \& Mintzes, J. J. (2002). "Cognitive structure and the affective domain: On knowing and feeling in biology", International Journal of Science Education, 24(6), 645-660.

[24] Sönmez, V. (1985). Program geliştirmede öğretmen elkitabı, (1.Baskl).[Teacher's Handbook of Curriculum Development $\left(1^{\text {st }}\right.$ Ed.)] Ankara:AnıYayıncılık. 
[25] Sönmez, V. (1987). Sevgi eğitimi.[Love education] Ankara: AnıYayıncilik.

[26] Sönmez, V. (1988). "Psikomotor alanın yeniden kodlanmas1"[Recoding psychomotor domain]Journal of Human Sciences, Middle East Technical University, ValumeV11, (1), 141-158.

[27] Sönmez, V. (1989). "Eğitiminbiyo-teknolojik temelleri" [Bio-technological basis of education], Fen ve Yabanci Dil Öğretmenlerinin Yetiştirilmesi Sempozyumu, Ankara: Hacettepe Üniversitesi Eğitim Fakültesi.

[28] Sönmez, V. (2012). Program geliştirmede ögrretmen elkitabı.(17. Baskı)[Teacher's Handbook of Curriculum Development (17 ${ }^{\text {th }}$ Ed.)]Ankara: AnıYayıncılık.

[29] Sönmez, V. (2015). Öğretim ilke ve yöntemleri,(8.
Baskl).[Teaching principles and methods] Ankara: AnıYayıncilık.

[30] Sönmez, V.,\& Alacapınar, F.G.(2014). Örneklendirilmiş bilimsel araştırma yöntemleri. (3. Baskı). [Scientific research methods with examples] Ankara: AnıYayıcılık

[31] Wang, C. K. J.,\& Liu, W. C.(2008). "Teacher's motivation to teach national education in singapore: a self-determination theory approach", Asia Pacific Journal pf Education, 28: 4 (2008), s.395-410.

[32] Zajonc, A. (2006). "Cognitive-affective connections in teaching and learning: the relationship between love and knowledge". Journal of Cognitive Affective Learning, 3/1, (2006), s. 1-9. 